This is a self-archived - parallel published version of this article in the publication archive of the University of Vaasa. It might differ from the original.

\title{
Knowledge sharing motives and value co- creation behavior of the consumers in physiotherapy services: a cross-cultural study
}

Author(s): Bhatti, Waheed Akbar; Glowik, Mario; Arslan, Ahmad

Title: Knowledge sharing motives and value co-creation behavior of the consumers in physiotherapy services: a cross-cultural study

Year: $\quad 2020$

Version: Author accepted manuscript

Copyright (C)2020 Emerald Publishing Limited. This manuscript version is made available under the Creative Commons Attribution-NonCommercial 4.o International (CC BY-NC 4.0) license, https://creativecommons.org/licenses/by-nc/4.o/

Please cite the original version:

Bhatti, W. A., Glowik, M. \& Arslan, A. (2020). Knowledge sharing motives and value co-creation behavior of the consumers in physiotherapy services: a cross-cultural study. Journal of Knowledge Management. https://doi.org/10.1108/JKM-04-2020-0273 


\title{
Knowledge Sharing Motives and Value Co-creation Behavior of the Consumers in Physiotherapy Services: A Cross-Cultural Study
}

\begin{abstract}
Purpose: We investigate the role of consumers' (patients') motives in knowledge sharing and value co-creation with the service provider in the context of physiotherapy services.

Design/methodology/approach: We perform Smart PLS-SEM analysis of the physiotherapy services users' data from Germany and Pakistan.

Findings: Our results show in both consumer groups individualizing, empowering, and development motives are common influences on the willingness to share knowledge leading to value co-creation. However, the relating, ethical, and concerted motives show varying influences in the data set.
\end{abstract}

Research Implications: A key research implication relates to specifying the link between consumer knowledge sharing and value creation and the role of cultural factors in this context. It is one of the first studies to undertake a comparative analysis in this specific context by highlighting the changing role of consumers from collective and individualistic societies, in influencing service provision through participation in the service exchange.

Practical Implications: For the managerial audience, our paper highlights the importance of being sensitive to cultural elements as they tend to influence personal knowledge sharing by the consumer, especially in the wellbeing sector, which ultimately influences the value cocreation.

Originality: The current paper is one of the first studies (at least to our knowledge) focusing on the knowledge sharing motives of consumers in the specific context of physiotherapy services leading to value co-creation. Moreover, specific focus on individual consumer's motives and their role in comparative, cross-cultural settings, adds further value to the contribution of our study.

Keywords: Consumer experience, Knowledge Sharing, Value Co-Creation, Wellbeing Sector 


\section{Introduction}

In an increasingly competitive landscape, organizations are struggling to engage with their consumers and motivate them to participate in value co-creation activities by sharing knowledge with them (e.g. Archer-Brown and Keitzmann, 2018; O'Hern and Rindfleisch, 2010). It has further been argued that managers need specific guidance on how to develop and implement a value co-creation strategy that will move beyond the metaphorical view of value co-creation used in many studies (e.g. Grönroos and Gummerus, 2014; Schuler et al., 2019). At the same time, the role of (service) context for better understanding of value co-creation has been highlighted in recent studies (Caputo et al., 2019; Etgar, 2008; Neghina et al., 2017; Vargo and Lusch, 2004; 2008). Prior research on value co-creation has been undertaken in specific sectors like education (e.g. Díaz-Méndez and Gummesson, 2012; Judson and Taylor, 2014), hospitality (Camilleri and Neuhofer, 2017; Chathoth et al., 2013) as well as in healthcare and wellbeing sector (e.g. Frow et al., 2016; McColl-Kennedy et al., 2012; Sweeney et al., 2015).

Service context has been referred to as an important element that shapes value cocreation and needs to be critically examined (Grönroos and Voima, 2013; Rajan and Read, 2016). Due to the growing interest in this research area, McColl-Kennedy et al. (2017) suggest investigating the influence of participants (consumers) on the value co-creation process so as to achieve their individual choice goals. In the specific setting of healthcare and wellbeing services, outcomes have long been identified to be linked with consumer (service users) activities (e.g. Bitner et al., 1997), leading to their important role in value co-creation (e.g. McColl-Kennedy et al., 2017). Hence, knowledge sharing behavior of consumers with service providers is important to analyze in order to have a better understanding of value co-creation in this context. This argument forms the starting point of our paper.

We aim to analyze the individual motives that generally have the most leverage for knowledge sharing with service providers leading to co-creating of value. We delve into different motives linked with consumer knowledge sharing and attempt to highlight the role of cultural differences in this context. Collectivistic, or individualistic cultural dimensions can potentially influence the patients' behavior including knowledge sharing or value co-creation. In the current paper, we examine the influence of motives on individuals' willingness to share knowledge for value co-creation among physiotherapy consumers and compare the findings in the cross-cultural settings of Germany and Pakistan. Physiotherapy services are knowledge- 
intensive professional services. Knowledge intensity and workforce professionalism create value for and with consumers and thus are ideally suited for our research subject of co-creation (e.g. Neghina et al., 2017). Therapies involve the interaction between the therapist and patient in a process where body and muscle movement potentials are examined and assessed. Common goals are agreed upon with the patient, using knowledge and skills based on the therapist's qualifications (World_Confederation_of_Physical_Therapy, 2017). It should further be noted that we use the term '(physiotherapy) consumer,' following Holdford (2007), which seems to be the most appropriate and common terminology in the course of studying important determinants of co-creation in healthcare and wellbeing services (e.g. Turek and Owczarek, 2015).

Our study contributes to the extant knowledge sharing, value co-creation, and service sector literature. It is one of the first studies to specifically highlight the cultural differences and their influence on how German versus Pakistani consumers deal with physiotherapy services by willingly sharing the knowledge that leads to value co-creation. Prior service sector focused research has established that individualistic vs. collectivistic cultural dimensions influence service context including customer satisfaction significantly (e.g. Mattila and Peterson, 2004; Chen et al., 2015; Lamb et al., 2020; Mai et al., 2020). However, so far, no prior study has specifically addressed value co-creation by consumers in the specific context of the wellbeing service sector. Hence, our paper study aims to fill this clear gap in the literature. By specifically focusing on consumer (patient) motives for knowledge sharing in the unique context of physiotherapy services, we highlight the importance of associated wellbeing services as a research focus. This aspect is important as these services have not received much attention by prior researchers, compared to the general healthcare and medical services which have been significantly researched.

The paper hereon continues with the presentation of theoretical background followed by a discussion on study hypotheses. The next section presents the methodology and analysis of the empirical findings. Concluding remarks, managerial implications, and future research directions conclude the paper.

\section{Theoretical Background}

"Service is a perspective on value creation rather than a category of market offerings" (Edvardsson et al., 2005, p. 118). During the last couple of decades, the traditional perspective 
that the value for consumers is embedded in products resulting from the producers' manufacturing processes as an output, has been questioned by different scholars. Such studies argue that value for consumers is linked to their involvement in the value generation processes (e.g. Ravald and Grönroos, 1996; Normann, 2001; Vargo and Lusch, 2004; Grönroos, 2006: Grönroos and Voima, 2013; Hollebeek et al., 2019). In their original work focusing on the service-dominant logic, Vargo and Lusch $(2004,2008)$ presented the consumers as coproducers. Later, they adapted this perspective to highlight the consumers as value co-creators. In the service logic, actors generate value in their interactions, defined as 'situations in which the interacting parties are involved in each other's practices' (Grönroos and Voima, 2013, p. 141). The actors generate this value for themselves and create it with other parties (Berthon and John, 2006; Etgar, 2008; Vargo and Lusch, 2004; 2008). Grönroos (2008: p. 303) defined the value for consumers as, "Value for customers means that after they have been assisted by a self-service process (cooking a meal or withdrawing cash from an ATM) or a full-service process (eating out at a restaurant or withdrawing cash over the counter in a bank) they are or feel better off than before." This is, clearly, an operational definition, representing what the value creation process is about (Grönroos, 2011).

Our paper follows Grönroos' (2012, p. 6) definition of value co-creation which is, "joint collaborative activities by parties' indirect interactions, aiming to contribute to the value that emerges for one or both parties." The nature of the services process is their most distinguishing characteristic is to assist consumers' daily practices (Grönroos, 2006). Consumption is a selfservice process in most cases. However, in the case of a full-service service provider, the situation is significantly different from the self-service process. In full-service, the service provider engages with the consumers' practices and can interfere with their consumption process. The service provider learns from the consumers (i.e. knowledge sharing from consumer to provider) and provides them with customized options rather than the standardized ones as is the case in a self-service setting. Moreover, the service provider can adjust to consumers' potential preferences that go further than initial expectations.

For the current study, we use the typology of Karpen et al. (2012), which recognized six strategic value co-creation interactions among consumers and the service providers. These value co-creation drivers influence consumer motives to engage in the value co-creation with the service provider. Neghina et al. (2017) also adapted this typology into six dimensions of value co-creation at the micro-level of service interaction. In agreement with expectancy theory 
(Mitchell, 1974; Vroom, 1964), from the consumer's viewpoint, the identified dimensions translate into consumer motives to engage in knowledge sharing with producers leading to value co-creation, as these represent the value types that the consumer expects to derive from the interaction activity. These six dimensions (Karpen et al., 2012) are (1) individualizing motives, which pertain to forming a common understanding of the consumer's resources, roles and desired outcomes; (2) relating motives, which refer to improving the emotional and social connection with other consumers or the service provider; (3) developmental motives, which are linked to the growth of the consumer's resources; (4) empowering motives, which are connected to the desire to negotiate the power to influence the service routine or the expected outcome; (5) ethical motives to require fair and moral guidelines for the service interaction; and (6) concerted motives, which refer to synchronizing efforts with the objective of engaging in relevant, satisfying and timely interactions.

The significance of co-creation motives differs across service contexts (cultures) due to consumers' perceived expectations (e.g. Iglesias, 2004). It has been argued that social structures which are closely linked to culture of a society tend to be 'empirically unobservable rules and resources that directly influence social activities' (Edvardsson et al., 2011, p. 330). These social structures tend to influence the consumer perceptions of the service contexts in question. Perceptions are driven by individual consumer experiences (Cadotte et al., 1987) which lead the consumers to develop certain expectations, norms, and a mental model vis-à-vis their roles in different service contexts. Consumer motivations do not exist in a vacuum but are instead connected directly to objectives and intentions that are molded by the social context in which the consumer operates. Explicitly, consumers rely on the action-outcome expectations that are valuations 'of the likelihood that the initiation of goal-directed behaviors will lead to goal achievement' (Bagozzi and Dholakia, 1999, p. 28). These expectations influence the objectives which consumers set, as well as influence the way in which behavioral intentions are constructed, and the interactions they consider achieving these objectives. The role of common understandings (for example, between consumers and service providers) in determining consumer expectations and the behavior are groomed via 'prescriptive and proscriptive rules for social conduct and meaning ascription' (Deighton and Grayson, 1995, p. 661). Hence, the consumers engage in co-creation activities emanating from their knowledge sharing, when they expect different value outcomes from these interactive activities. It has been argued that the constituents of value-creating activity are not located exclusively with a provider or exclusively with the receiver, but between the service provider and receiver 'as productive exchange 
connections' (Ballantyne and Varey, 2006: p. 342). Hence this interaction is important to consider in this specific context. This discussion on the importance of service context in value co-creation is also substantiated by prior studies which have referred to the importance of cultural difference between individualistic and collectivistic societies. It has been argued that culture plays a significant role in influencing customers' beliefs regarding service quality and satisfaction (e.g. Li and Cai, 2012; Chen et al., 2015). Prior studies have further found out that even within the same service environment, different cultural orientations of customers can potentially result in differing service expectations and satisfaction levels (e.g. Rahman, 2019; Lamb et al., 2020). Prior service researchers have used 'individualism/collectivism' dimension widely in analyzing service quality and customer satisfaction in different contexts (e.g. Mattila and Peterson, 2004; Rahman, 2019; Lamb et al., 2020; Mai et al., 2020). This specific aspect has not been addressed from the perspective of value co-creation in wellbeing services context, a gap in extant literature which our study is aiming to fill. Below, we present discussion and argumentation specific to the consumer motives for knowledge sharing and value co-creation, leading to presentation of the study hypotheses.

Neghina et al., (2014, p. 6) define individualizing motives as "collaborative actions between customers and employees aimed at establishing a mutual understanding of each other's resource integration processes, roles, and desired outcomes." This corresponds to the shift toward customization and individualization in services as also integrated into service logic (Payne et al., 2008). This shift enables choices and opportunities for consumers to express their individual wants, needs, and preferences, endorsing the individualizing motive of knowledge sharing and value co-creation (e.g. Karpen et al., 2012; Neghina et al., 2017). In this context, Gallan et al. (2013) refer that when a consumer experiences higher levels of positivity, the consumer is more willing to engage in favorable relationship activities characterized by sharing information, making suggestions, and engaging in co-decision making. Interactions between the consumer and staff provide opportunities for communicating essential information that facilitates positive service experience outcomes (Street et al., 2009). Individualized treatment by the service providers has been found to improve the trust with consumers which is very important for the success of such treatments in many cases (e.g. Hogarty, 2002). Moreover, individualized treatment and resulting trust has further been found to positively influence knowledge sharing by the consumers (e.g. Nambisan and Nambisan, 2009). Along with individualization motives relational motives are also important to consider as they are strongly linked with trust and open communications (e.g. Seiders et al., 2015). This open 
communication and presence of trust tend to act as a conduit for meaningful knowledge sharing, which positively support value co-creation. On the other hand, the findings of Tran et al. (2014) show that lack of such interactions based on open communication and trust can potentially obstruct the ability of consumers to make well-informed decisions, as well as result in anxiety concerning their health conditions. Hence, in such circumstances, knowledge sharing and resulting value co-creation will be non-existent between the consumer and service provider.

Based on the above discussion, we hypothesize that:

Hypothesis 1. Consumers' individualizing motives positively influence their willingness to cocreate value.

Hypothesis 2. Consumers' relating motives positively influence their willingness to co-create value.

In healthcare and wellbeing literature, consumer empowerment has emerged as an important factor since last couple of decades (Wright et al., 2006; Edmunds et al., 2019). It has been argued that this consumer empowerment has played an important role in shift from healthcare being viewed as a product to its perception as a service, where the consumer plays an important role including knowledge sharing (Fuller et al., 2009; Huang et al., 2019). The prior studies have further stressed the import role of communication and knowledge sharing to support consumer empowerment. Along with the consumers, for the service providers; this consumer empowerment also brings benefits including costs saving as well as improved health outcomes (Michie et al., 2003; Edmunds et al., 2019). Prior literature has further argued that when consumers take an active role in the process and develop a level of mastery in managing their ongoing illness, it results in increased self-efficacy and satisfaction (e.g. Guo et al., 2013). Therefore, consumer empowerment has been found to be positively associated with value cocreation as well (Fuller et al., 2009; Black and Veloutsou, 2017). It is further important to mention that in context of communication, the importance of clear and open communication during the whole process has been stressed by the prior scholars (e.g. Ballantyne and Varey, 2006; Razmerita et al., 2016). This can help the service providers to interactively respond to the consumer service needs as well as avoid arising of potential ethical concerns regarding their rent seeking behavior from the perspective of consumers (e.g. Ballantyne and Varey, 2006; Edmunds et al., 2019). Prior service research indicates among the reasons for consumers, a key reason to switch service providers is their dishonest or unethical conduct (Keaveney, 1995; 
Joosten et al., 2017). It has further been argued that expectation of fair and equal treatment plays a major role in consumers' engagement with service providers (e.g. Williams and Aitken, 2011; Joosten et al., 2017). Hence, ethical concerns may hinder knowledge sharing and value co-creation by consumers in cases where they view their treatment as being unfair.

Based on the above discussion, we hypothesize that:

Hypothesis 3. Consumers' empowerment motives positively influence their willingness to cocreate value.

Hypothesis 4. Consumers' ethical motives positively influence their willingness to co-create value.

Lutfey (2004: p. 343) defines compliance as 'the degree to which healthcare consumer behavior coincides with medical advice.' Overall compliance with successful medical (and wellbeing) procedures and processes is suggested to be an important outcome of interpersonal interactions during the consumer's (patient's) interaction with medical (healthcare) staff. Treatment results are questionable when they are narrowly based on a single treatment plan prescribed by the healthcare practitioners (Hausman, 2004; Lutfey, 2004). Interpersonal components, such as encouragement and support, are known to promote compliance, and it is suggested that they should be stimulated gradually by developing the positive influencing reactions (Seiders et al., 2015). In prior studies focusing on knowledge sharing dynamics in organizations, it has been argued that individuals (e.g. employees in an organization) tend to share knowledge with others if they see developmental outcomes out of it (Gagne, 2009). In context of tourism services as well as banking, prior studies have also argued that developmental (value enhancement) motives tend to positive influence the consumers to share their knowledge (including experiences) with the service providers (e.g. Tobbin, 2012; Bilgihan et al., 2016). We argue that similar argumentation is also valid in case of knowledge sharing between consumer and provider because developmental motives can be a significant motivational factor for patients to share knowledge and co-create value. Moreover, concerted motives have been found to positively influence knowledge sharing leading to value cocreation by consumers in a physical store setting in a recent study by Schuler et al. (2019). Hence, both developmental and concerted motives have the potential to support knowledge sharing value co-creation between consumers and healthcare service provider.

Based on the above discussion, we hypothesize that: 
Hypothesis 5. Consumers' developmental motives positively influence their willingness to cocreate value.

Hypothesis 6. Consumers' concerted motives positively influence their willingness to co-create value.

Earlier studies (e.g. Yi and Gong 2013; Yi et al., 2011) propose that there are two types of intended co-creation behavior, namely, active and passive. According to Yi and Gong (2013), active and passive behaviors consist of four dimensions. Active participation behavior consists of advocacy, feedback, helping, and tolerance. Passive participation behavior consists of the dimensions of information sharing, information seeking, personal interaction, and responsible behavior. This work adopts a similar contrast, wherein consumers' intended cocreation behavior is reflected in the active and passive dimension. In-service settings, the interactions which take place between healthcare staff and consumers play an important role. These interpersonal interactions increase and encourage open communication that facilitates the provider's ability to provide concern, empathy, and trust for the consumer (Hausman, 2004). In context of such interpersonal interaction, willingness to share knowledge has been referred as a key aspect of success of relevant organizational processes (e.g. Keszey, 2018). This argument is also applicable in case of consumer's willingness to share knowledge with physiotherapy service providers. Specifically, Hawkins et al. (2013) have stressed a strong interplay between consumer motives and willingness to co-create and, as a result, their intended co-creation behavior. Therefore, following Neghina et al. (2017), we expect the willingness to co-create to remain a strong determinant of consumers' intended co-creation behavior. Hence, we deduce:

Hypothesis 7. Willingness to co-create positively influences the consumers' co-creation behavior.

\section{Research Methodology}

\subsection{Data Sample}

We have selected physiotherapy providers as the subject of our empirical research. Physiotherapy is described as a science-based profession that takes a 'whole person' approach to health and wellbeing, which includes the patient's general lifestyle. Consequently, at the core of the service is the patient's involvement in their care, through education, awareness, empowerment, and participation in their treatment (Chartered_Society_of_Physiotherapy, 
2013). These services are provided only by relatively high educated and certified therapists to individuals in order to develop, maintain, and restore maximum movement and functional ability. The service is provided in circumstances where movement and function are threatened by aging, injury, pain, diseases, disorders, conditions or other environmental factors and with the understanding that functional movement is central to what it means to be healthy (World_Confederation_of_Physical_Therapy, 2017).

The physiotherapy service blends scientific knowledge with a broader view to help restore and maintain health while working with individuals' social as well as physical wellbeing (Nicholls and Gibson, 2012). The service demands on the profession are closely linked to working with and empowering the patients to share decision-making and evaluation of their rehabilitation (Hoogeboom et al., 2014). The physiotherapist, together with the patient, sets realistic but challenging goals. It is crucial that the patient him/her-self sets the goals, and that the patient experiences that the goals are achievable. This implicates that the physiotherapy intervention must be meaningful to the patient, to assure the possibility of adherence to physiotherapy interventions (Papadimitriou, 2008). The knowledge base of physiotherapy is complex and ever-changing (Shaw and DeForge, 2012), which implicates the need to understand co-constructive learning processes to improve physiotherapy interventions and their results.

Our questionnaire was designed and adapted on item loadings defined in the literature and previously applied in co-creation studies in service industries (Neghina et al., 2015; Neghina et al., 2017). We adopted three items for the individualizing motive construct. The relating motive was measured using two items. The empowering motive was measured by adapting three items. We employed three items each for ethical motive, developmental motive, and concerted motive. We adopted three items for willingness to share knowledge and five consumer co-creation behavior for our measurement scale.

In our questionnaire, respondents could express their preferences within a seven-point Likert scale. Likert scale items target the physiotherapy consumer's Willingness to co-create with the physiotherapy, their individualizing and relating motives to co-create, empowering, ethical, and developmental as well as concerted motives for their co-creation with the therapist. The questionnaire also included additional space for individual comments and recommendations by each interviewee. Finally, the age, education, and gender of each interviewee were recorded, but without the name of the participant (anonymous database). 
Quantitative data related to the physiotherapy consumer's intention to understand consumers' co-creation behaviors and their previous co-creation experiences. Following a 'reconstruction logic' based on the frequencies and correlations between standardized and codified item loadings, our quantitative research methods target further development of the co-creation theory with a particular focus on healthcare services (Creswell, 2009; Neuman, 2006).

\subsection{Survey Administration and Sample Characteristics}

For our empirical field research, we have selected physiotherapy service providers in Pakistan which are part of the public hospitals, and in Germany, they are private entities offering services to public and privately insured individuals. Based on this criterion, we preselected physiotherapy providers located in Berlin and Brandenburg, Germany, and in Rawalpindi, Islamabad and Lahore in Pakistan. In the next step, during April and August 2018, we personally visited each preselected physiotherapy provider to brief its staff and management about our research intentions and aims. Out of 50 physiotherapies we reached out to distribute 486 questionnaires we received 167 filled replies, which equals a return rate of 34 per cent. Our respondents are all receiving physical physiotherapy services. In Pakistan 9 Public hospitals were contacted by us in Rawalpindi/Islamabad and Lahore in Pakistan and 4 hospitals in Rawalpindi/Islamabad and 3 in Lahore agreed to cooperate in our research. The data collection was carried out from October 2018 to March 2019. Out of 900 distributed questionnaires 344 filled replies were received, which equals a return rate of 38 percent. There were no missing values.

Finally, our sample of Germany 167 questionnaires indicates a predominance of patients aged 50 years and older (57 per cent). Most of the respondents had completed vocational training (43 per cent) or held an academic degree (40 per cent). The sample mainly consists of female respondents (female: 59 per cent, male: 34 per cent, no answer: 7 per cent). Our sample from Pakistan of 344 questionnaires indicated patients aged 50 years and older (64 percent). The respondents had completed high school/ vocational training (43 per cent) or hold an academic degree (30 per cent) with remaining having some school or none. The sample mainly consists of male respondents (female: 34 per cent, male: 66 per cent). We paid particular attention to introducing our questionnaire contents to each physiotherapy provider in order to minimize potential error bias due to misunderstandings of terms and meanings of the questions and answer categories. Physiotherapy providers that expressed their willingness to participate in the project were promised that they would receive our report containing major research 
results concerning consumer co-creation determinants related to physiotherapeutic service treatments.

\section{Analysis and Results}

\subsection{Measurement Model}

We employed SmartPLS to perform PLS-SEM for data analysis (Ringle, 2015). The objective of this study is to explore the extent to which physiotherapy consumers' motives play a critical role in their Willingness to co-create value in an ongoing relationship. The influence of consumer motives on their Willingness to share knowledge for value co-creation has rarely been examined in prior research in the context of physiotherapy services in an integrated model.

Even though PLS-SEM estimates both the measurement model and the structural model simultaneously, we pursued the procedure recommended by Hulland (1999) in evaluating models. The estimated model analysis and interpretation took place in two stages: firstly, the reliability and assessment of the measurement model, and secondly, testing of the structural model. We validated the study measurement model as suggested by Hair et al. (2011) by assessing the individual-item reliabilities, convergent, and discriminant validity. The individual item reliabilities were first assessed by the loadings between the indicator and its latent variables. All the individual item reliabilities' loadings are above the level of 0.7 , as recommended by Gotz et al. (2010) on their respective latent variables, indicating a high degree of individual item reliability. The construct reliability for each of the latent constructs was calculated using composite reliability. The composite reliability for all the constructs was higher than the level of 0.6 recommended by Gotz et al. (2010), thus indicating that the reliabilities of all the constructs are good. Our data passes this evaluation too, and hence, discriminant validity is assured.

To assess the convergent validity of the reflective block of the model, Fornell and Larcker (1981) recommend an average variance extracted (AVE) with a value higher than 0.5. An AVE value of less than 0.5 is considered insufficient, as the greater variance is due to error variance rather than indicator variance (Gotz et al., 2010). As evident from Table 1, all latent constructs comply with the recommended minimum level of 0.5 . For that reason, all the latent constructs were found to be sound and satisfactorily valid. The research on PLS-SEM (Fornell and Larcker, 1981; Gotz et al., 2010) recommends that the average variance extracted (AVE) is also helpful in the assessment of discriminant validity. Discriminant validity is proven if the 
square roots of the AVEs of the latent variables are higher than the correlations amongst the latent variables (Chin, 1998; Fornell \& Larcker, 1981; Gotz et al., 2010). Our results in Table 1 demonstrate that the data passed this test too and hence assuring discriminant validity.

\section{INSERT TABLE 1 HERE}

For PLS-SEM, common method bias is detected through a full Collinearity assessment approach (Kock, 2015). The occurrence of a variance inflation factors (VIFs) greater than 3.3 is recommended as a pathological collinearity indicator, and it is also a sign that a tested model may have common method bias. Therefore, if VIF values should be lower than the 3.3 thresholds, the model can be considered free of common method bias (Hair et al., 2017; Kock, 2015). For both models, the values of VIF were below 2.0, and this is indicative that the model is free from common method bias.

\subsection{Structural Estimates}

Concerning the main effects of the structural model, is assessed by looking at R2 (i.e., coefficient of determination) and F2 (i.e. for overall effect) for the dependent variable, path loadings (i.e. standardized b) and significance levels (Gotz et al., 2010; Hair et al., 2011). The $\mathrm{R} 2$ for co-creation behavior in model 1 is 0.22 , which suggests that the independent variables explain $22 \%$ of the variance in the dependent variable of co-creation behavior. The $\mathrm{R} 2$ for cocreation behavior in model 2 is 0.59 , which suggests that the independent variables explain $59 \%$ of the variance in the dependent variable of co-creation behavior. We used a bootstrapping method of sampling by 300 bootstrapping runs and generated t values (Chin, 1998). Table 2 indicates the results of the structural model. The model is used to examine the influence of physiotherapy consumer motives on the Willingness to share knowledge.

Following the six-dimension approach of value co-creation at the micro-level according to Neghina et al. (2015) our empirical study provides the following evidence: Concerning the patients' individualizing motives, most of the respondents would like to contribute with their knowledge and skills during their treatment. Also, they want to make sure that their treatments are an optimal fit for their individual needs. Consistent with expectation $\mathrm{H} 1$, the individualizing motive is positively related to willingness to share $(b=0.113 ; p \leq 0.18 ; b=0.149 ; p \leq 0.011$, is rejected in first data set and accepted in second data set). 
Concerning the category of relating motives, which refers to improving both the emotional and social connection with other consumers or the service provider, the study delivers evidence that Pakistani and most of the German respondents did not intend to influence public opinion, for example through social media. Thus, relating motives in terms of physiotherapy treatments in our data sets depict a similar finding in our sample. Hypothesis $\mathrm{H} 2$, concerning the positive impact of relating motives on willingness to share, $(b=-0.128 ; p$ $\leq 0.13 ; \mathrm{b}=0.013 ; \mathrm{p} \leq 0.768$, is rejected in both data sets).

\section{INSERT TABLE 2 HERE}

Concerning the category of empowering motives, that is the desire to use power in influencing the result, almost half of the respondents would like to have an active influence over the final output. Hypothesis $\mathrm{H} 3$, the influence of empowering motives on willingness to share, $(\mathrm{b}=0.159 ; \mathrm{p} \leq 0.09 ; \mathrm{b}=0.183 ; \mathrm{p} \leq 0.001$, is accepted in both data sets $)$. Regarding ethical motives, almost all respondents claim that they want to be treated honestly and fairly during their physiotherapy treatment. Hypothesis H4, concerning the less likely influence of ethical motives on willingness to share, $(b=0.019 ; p \leq 0.84 ; b=0.161 ; p \leq 0.007$, is rejected in first and accepted in second data set).Concerning developmental motives, which are related to the patients' knowledge and skills, more than half of the respondents would like to gain new knowledge in the course of cooperation with their physical therapy. More than half of the respondents would like to learn new things in the course of cooperation on their physical therapy.

Hypothesis H5, concerning the likely influence of developmental motives on willingness to share, $(b=0.241 ; p \leq 0.013 ; b=0.225 ; p \leq 0.000$, is accepted in both data sets). Concerning concerted motives, which refer to synchronizing efforts to engage in the comfortable and timely treatment, most agree that their physical therapy should be able to make conclusions for improving their treatments as a result of this project. Hypothesis H6, concerning the influence of concerted motives on willingness to share, $(b=0.052 ; p \leq 0.51 ; b$ $=0.161 ; \mathrm{p} \leq 0.008$, is rejected in first and accepted in second data set).

Most of the respondents are willing to cooperate actively with the physiotherapy. Also, more than half of respondents admit that they are willing to invest time (e.g., exercises at home) in this cooperation project. Most respondents are mentally and physically well-prepared to 
contribute actively to the treatment success. Moreover, they would like to contribute time and efforts to maximize treatment success. Hypothesis H7, concerning the influence of willingness to share knowledge on co-creation behavior, $(b=0.469 ; p<0.000 ; b=0.768 ; p \leq 0.000$, is accepted in both data sets).

To sum up, physiotherapy consumers' individualizing motives influence most of our respondents in both countries as they contribute with knowledge and skills to ensure aligning the treatment with their needs. This support for the importance of individualizing motives is in line with findings of prior studies (e.g. Hogarty, 2002; Gallan et al., 2013). The relating motives present similar choices in our data set respondents as both do not intend to share their experience through social media, as they believe their social media or otherwise sharing will not influence other consumers or service providers. Hence, cultural differences were not visible concerning these motives. However, both data set respondents would like to exercise power to influence the service as well as the fair and honest provision of treatment. This importance of empowerment motives supports the findings of prior studies focusing on similar topics for both groups of respondents (e.g. Wright et al., 2006; Fuller et al., 2009; Edmunds et al., 2019). Prior studies (e.g. Ballantyne and Varey, 2006; Joosten et al., 2017; Edmunds et al., 2019) have found that physiotherapy consumers change their service provider among other reasons e.g., due to arising ethical concerns regarding their rent seeking attitude or unfair conduct. In our results, this aspect was more visible for Pakistani consumers compared to the German ones. A partial explanation of the finding can be due to the fact that in Pakistan, the respondents were being treated in public sector hospitals, where quality and satisfaction issues may be more prevalent than the German consumers who were being treated in the private wellbeing services sector.

For the concerting motives, which depict synchronizing effort for timely and comfortable treatment, German consumers expect the service provider to make decisions concerning treatment, whereas Pakistani consumers wish to decide themselves for improvement of received physiotherapy service. Hence, cultural differences were also clearly visible concerning these motives. Most of the study respondents in both countries are willing to cooperate with the service provider physiotherapist actively. They are willing to invest time by exercising at home, following the plan in this cooperative service engagement. The physiotherapy consumers are physically and mentally well-prepared to contribute actively to the treatment success. 


\section{Discussion}

Understanding in what manner service features or environment influence individual consumer motives to willingly share knowledge and co-create value in various service settings is paramount to the successful development of co-creation interactions of value. The current paper analyzed if the physiotherapy service context affects the consumer's motives, which are more likely to influence their willingness to share knowledge and value co-creation behavior. We present empirical data from Germany and Pakistan, comparing for the contextual nature of consumer knowledge sharing and value co-creation (e.g. Edvardsson et al., 2011; Edmundson et al., 2019). Our results show that individual motives influence their willingness to share, participate in value creation activities during, and after service exchange concerning the expected outcome or intended goal of the patient. Furthermore, service providers can offer new or alternative resources, opportunities for encouraging sharing to co-create, during service exchange practices. The results further indicate that patients are willing to participate in influencing the desired outcome of the treatment actively.

We find that the consumer's primary motives to share knowledge and co-create value are crucial when determining his/her willingness to engage in this process. Additionally, the emphasis of the research is on the argument that the significance of different motives may vary according to various service contexts. Our study further highlights the culture-specific tailoring need in physiotherapy services for value co-creation. Our results show in both consumers groups relating, empowering, and development motives are common influencers on Willingness to co-create value. However, the individualizing, ethical, and concerted motives show different influence in the data set. The results reveal that the German consumer does not wish to share acquired knowledge or experience with consumers or potential consumers. This can be because German society is individualistic as per Hofstede cultural dimensions (Hofstede, 2020). On the other hand, Pakistan being a collectivistic society (Hofstede, 2020), as per cultural dimensions research, people are willing to share for collective wellbeing. About ethical motives, the German consumer is not influenced by her motives to share, whereas the Pakistani consumer is influenced by their ethical motives. As for concerted motives, German consumers prefer to be part of decision-making on treatment and related changes, unlike Pakistani consumers who seem to rely on conclusions taken by the physiotherapy service provider. The majority of respondents agree on the importance of gaining an active influence over the final output of their treatment (empowering motives). Hence, we receive support for the argument that knowledge sharing, and value co-creation is positively linked with an 
individual's empowerment feeling. The current study highlights the changing role of the wellbeing and healthcare consumer, bringing forth insights on how to improve the consumer service experience and level of satisfaction. As a result, in-depth knowledge regarding consumer relationship-driven service treatments fundamentally helps in improving the service providers' competitive positioning.

The service experience will ultimately influence his/her health as well as the quality of life. Person-centered care highlights the individual behind the patient (consumer), who has feelings, consumer needs and a will, to engage the individual as an active partner in care and treatment and decision-making (Ekman et al., 2011). Moreover, person-centered care depends on the knowledge of the individual (e.g. Starfield, 2011). This care shares comparable features with patient-centeredness but places greater importance on the partnership between the consumer and the service-providing professionals, starting with the individual patient's narrative - emphasizing that the individual is the focus and starting point of care. The knowledge sharing and value co-creation activity is the outcome of explicit decision-making (Etgar, 2008) where the consumer pursues the fulfillment of their needs or goals through involvement in co-creation interactions. Therefore, the underlying consumer motives are essential for the consumer's willingness is to engage in co-creation activity.

\section{Implications, Limitations and Future Research Directions}

Our study offers both theoretical and managerial implications. A key theoretical implication relates to specifying the link between consumer knowledge sharing and value creation and the role of cultural factors in context of physiotherapy services. So far extant research on consumer knowledge sharing and value co-creation has not focused explicitly on the cross-cultural difference, especially in physiotherapy services settings. Our findings stress the need to expand theoretical analysis by specifically incorporating cultural factors in the analysis and discussion. Also, the wellbeing sector generally, and physiotherapy services specifically are rather scantly researched in relation to topics of consumer knowledge sharing and value co-creation. Due to the specific nature of sensitivities of consumer knowledge in this sector, our paper can be viewed as a stepping-stone towards further theoretical exploration on other dynamics associated in the wellbeing sector.

For healthcare and wellbeing sector managers, this research identifies the significance of accepting the importance of consumer motives' role in the activities and interactions on their 
perceived wellbeing. There is a need for wellbeing professionals to view the consumer as an essential knowledge conduit about and for enhancing the patients' wellbeing. Knowledge sharing by the consumers is vital for their treatment plans and needs to be encouraged. This sharing helps the service provider better understand the consumer's needs and plan for what will work best in that specific situation. Also, it is essential that co-working will lead to the identification of a set of practices best suited to maximizing patient wellbeing. Therefore, consumers should be encouraged to engage in various activities with their family and friends as well as to collect information from medical doctors and service providers. The service providers can enhance service experience through the management of the physical environment that enhances processes and routines and their people. To achieve a value-providing experience, the service provider must accept the importance of consumer motives, activities, and interactions for their perceived wellbeing.

Finally, we acknowledge the limitations of our paper and offer suggestions for future studies as well. A key limitation is that our paper focuses solely on physiotherapy services in Germany and Pakistan. Future studies can expand the cross-cultural analysis to other countries, as well as incorporate more specific cultural elements in their theoretical frameworks. Future studies can also probe other wellbeing services and compare their findings with ours to see if a generalized pattern of consumer knowledge sharing and value co-creation can be observed or not in the wellbeing sector. As mentioned earlier, a broader examination of types of valuecreation practices is required to enhance theoretical and empirical understanding of this concept. In this study, we identify six types based on the typology of Karpen et al. (2012), which influence their willingness to share knowledge. However, future studies can use a different typology and probe it in the wellbeing sector or any other sector, for that matter.

\section{References}

Alderson, W. (1957), Marketing Behavior and Executive Action, Richard D. Irwin, Homewood, IL.

American_Physical_Therapy_Association. (2012). Guidelines: Defining physical therapy in state practise acts BOD G03-00-16-38. Retrieved May 19, 2018.

Archer-Brown, C., and Kietzmann, J. (2018), "Strategic knowledge management and enterprise social media", Journal of Knowledge Management, Vol. 22 No. 6, pp.12881309.

Bagozzi, R.P. and Dholakia, U, (1999), "Goal setting and goal striving in consumer behavior," Journal of Marketing, Vol. 63 No. 4, pp. 19-32.

Bagozzi, R.P. and Yi, Y. (1988), "On the evaluation of structural equation models," Journal of the Academy of Marketing Science, Vol. 16 No. 1, pp. 74-94.

Ballantyne, D. and Varey, R.J. (2006), "Creating value-in-use through marketing 
interaction: the exchange logic of relating, communicating and knowing," Marketing Theory, Vol. 6 No. 3, pp. 335-48.

Balint, E. (1969), "The possibilities of patient-centered medicine", The Journal of the Royal College of General Practitioners, Vol. 17 No. 82, pp. 269-276.

Berghout, M., van Exel, J., Leensvaart, L. and Cramm, J.M. (2015), "Healthcare professionals' views on patient-centered care in hospitals", BMC Health Services Research, Vol. 15 No. 1, pp. 1-13.

Berthon, P. and John, J. (2006), "From entities to interfaces," in Lusch, R.F. and Vargo, S.L. (Eds), The Service-Dominant Logic of Marketing: Dialog, Debate and Directions, M.E. Sharpe, London, pp. 196-207.

Bilgihan, A., Barreda, A., Okumus, F., and Nusair, K. (2016), "Consumer perception of knowledge-sharing in travel-related online social networks", Tourism Management, Vol. 52, pp. 287-296.

Bitner, M.J., Faranda, W.T., Hubbert, A.R. and Zeithaml, V.A. (1997), "Customer contributions and roles in service delivery", International Journal of Service Industry Management, Vol. 8 No. 3, pp. 193-205.

Black, I., and Veloutsou, C. (2017), "Working consumers: Co-creation of brand identity, consumer identity and brand community identity", Journal of Business Research, Vol. 70, pp. 416-429.

Cadotte, E.R., Woodruff, R.B. and Jenkins, R.L. (1987), "Expectations and norms in models of consumer satisfaction," Journal of Marketing Research, Vol. 24 No. 3, pp. 305-14.

Camilleri, J., and Neuhofer, B. (2017). Value co-creation and co-destruction in the Airbnb sharing economy. International Journal of Contemporary Hospitality Management.

Caputo, F., Garcia-Perez, A., Cillo, V., and Giacosa, E. (2019). "A knowledge-based view of people and technology: directions for a value co-creation-based learning organisation", Journal of Knowledge Management, Vol. 23 No. 7, pp. 1314-1334.

Chartered_Society_of_Physiotherapy. (2013). What is physiotherapy? Retrieved June 20, $2017 \mathrm{http}: / / \mathrm{www} . c s p . o r g . u k / y o u r-h e a l t h /$ what-physiotherapy

Chathoth, P., Altinay, L., Harrington, R.J., Okumus, F. and Chan, E.S.W. (2013), "Coproduction versus co-creation: a process-based continuum in the hotel service context," International Journal of Hospitality Management, Vol. 32 March, pp. 11-20.

Chen, B., Vansteenkiste, M., Beyers, W., Boone, L., Deci, E. L., Van der Kaap-Deeder, J., ... \& Ryan, R. M. (2015). "Basic psychological need satisfaction, need frustration, and

need strength across four cultures", Motivation and emotion, Vol. 39 No. 2, pp. 216-236.

Chiang, C.F. and Jang, S.S. (2008), "An expectancy theory model for hotel employee motivation," International Journal of Hospitality Management, Vol. 27 No. 2, pp. 31322.

Chin, W. W. (1998). The partial least squares approach to structural equation modeling. In G. A. (Ed.), Modern methods for business research (pp. 295-336). New Jersey: LEA.

Christopher, M., Payne, A. and Ballantyne, D. (1991), Relationship Marketing: Bringing Quality, Customer Service, and Marketing Together. Oxford: Butterworth Heinemann

Cooper, R. G., and Kleinschmidt, E. J. (2007). Winning businesses in product development: The critical success factors. Research Technology Management, Vol. 50, pp. 52-66.

Creswell, J. W. (2009). Research design, qualitative, quantitative, and mixed methods approaches. London: Sage Publications.

Deighton, J. and Grayson, K. (1995), "Marketing and seduction: building exchange relationships by managing social consensus," Journal of Consumer Research, Vol. 21 No. 4, pp. 660-76.

Díaz-Méndez, M. and Gummesson, E. (2012), "Value co-creation and university teaching 
quality: consequences for the European Higher Education Area (EHEA)," Journal of Service Management, Vol. 23 No. 4, pp. 571-92.

Edmunds, M., Hass, C., \& Holve, E. (2019). Consumer Informatics and Digital Health: Solutions for Health and Health Care. Springer.

Edvardsson, B., Tronvoll, B. and Gruber, T. (2011), "Expanding understanding of service exchange and value co-creation: a social construction approach," Journal of the Academy of Marketing Science, Vol. 39 No. 2, pp. 327-39.

Edvardsson, B., Frow, P., Jaakkola, E., Keiningham, T. L., Koskela-Huotari, K., Mele, C., \& Tombs, A. (2018). Examining how context change foster service innovation. Journal of Service Management, Vol. 29 No. 5, pp. 932-955.

Ekman, I., Swedberg, K., Taft, C., Lindseth, A., Norberg, A., Brink, E., Carlsson, J., DahlinIvanoff, S., Johansson, I.-L., Kjellgren, K., Lidén, E., Öhlén, J., Olsson, L.-E., Rosén, H., Rydmark, M. and Sunnerhagen, K.S. (2011), "Person-centered care: ready for prime time", European Journal of Cardiovascular Nursing, Vol. 10 No. 4, pp. 248-251.

Elg, M., Engström, J., Witell, L. and Poksinska, B. (2012), "Co-creation and learning in healthcare service development", Journal of Service Management, Vol. 23 No. 3, pp. 328343.

Epstein, R.M., Franks, P., Fiscella, K., Shields, C.G., Meldrum, S.C., Kravitz, R.L. and Duberstein, P.R. (2005), "Measuring patient-centered communication in patientphysician consultations: theoretical and practical issues", Social Science \& Medicine, Vol. 61 No. 7, pp. 1516-1528.

Etgar, M. (2008), "A descriptive model of the consumer co-production process," Journal of the Academy of Marketing Science, Vol. 36 No. 1, pp. 97-108.

Fisk, R. P., Brown, S. W., \& Bitner, M. J. (1993). Tracking the evolution of the services marketing literature. Journal of Retailing, Vol. 69 No. 1, pp. 61-103.

Frow, P., McColl-Kennedy, J.R. and Payne, A. (2016), "Co-creation practices: their role in shaping a health care ecosystem," Industrial Marketing Management, Vol. 56, pp. 2439.

Füller, J., Mühlbacher, H., Matzler, K., \& Jawecki, G. (2009). Consumer empowerment through internet-based co-creation. Journal of management information systems, 26(3), 71-102.

Gagné, M. (2009). "A model of knowledge-sharing motivation", Human Resource Management: Published in Cooperation with the School of Business Administration, The University of Michigan and in alliance with the Society of Human Resources Management, Vol. 48 No. 4, pp. 571-589.

Gallan, A. S., Jarvis, C. B., Brown, S. W., and Bitner, M. J (2013), "Customer Positivity and Participation in Services: An Empirical Test in a Health Care Context," Journal of the Academy of Marketing Science, Vol. 41 No. 3, pp. 338-356.

Götz, O., Liehr-Gobbers, K. and Krafft, M. (2010), "Evaluation of structural equation models using the partial least squares (PLS) approach," in Handbook of Partial Least Squares. Springer Berlin Heidelberg, pp. 691-711.

Grönroos, C. (1990). "Relationship approach to marketing in service contexts: The marketing and organizational behavior interface", Journal of Business Research, Vol. 20, No.1, pp. 3-11.

Grönroos, C. (2006). "Adopting a service logic for marketing", Marketing theory, Vol. 6 No. 3 , pp. 317-333.

Grönroos, C. (2008). "Service logic revisited: who creates value? And who cocreates?". European business review. Vol. 20 No. 4, pp. 298-314.

Grönroos, C. (2011). "Value co-creation in service logic: A critical analysis". Marketing theory, Vol. 11 No. 3, pp. 279-301. 
Grönroos, C (2012). Conceptualising value co-creation: A journey to the 1970s and back to the future, Journal of Marketing Management, Vol. 28 No. 13-14, pp. 1520-1534.

Grönroos, C. and Gummerus, J. (2014), "The service revolution and its marketing implications: service Logic vs service-dominant logic," Managing Service Quality, Vol. 24 No. 3, pp. 206-29.

Grönroos, C. and Voima, P. (2013), "Critical service logic: making sense of value creation and co-creation," Journal of the Academy of Marketing Science, Vol. 41 No. 2, pp. 133-50.

Guo, L., Arnould, E. J., Gruen, T. W., \& Tang, C. (2013). Socializing to co-produce pathways to consumers' financial well-being. Journal of Service Research, Vol. 16 No. 4, pp. 549-563.

Hair, J. F., Ringle, C. M., and Sarstedt, M. (2011), "PLS-SEM: Indeed a silver bullet. Journal of Marketing Theory and Practice, Vol. 19 No. 2, pp. 139-152.

Hair, J. F., Hult, G. T. M., Ringle, C. M., \& Sarstedt, M. (2017). A primer on partial least squares structural equation modeling (PLS-SEM) (2nd ed.). Thousand Oaks: Sage.

Hausman, A. (2004). Modeling the patient-physician service encounter: Improving patient outcomes. Journal of the Academy of Marketing Science, Vol. 32 No. 4, pp. 403-417.

Hawkins, D.I., Mothersbaugh, D.L. and Best, R.J. (2013), Consumer behavior: building marketing strategy. McGraw-Hill Irwin, New York. Heinonen.

Helkkula, A. and Kelleher, C. (2010), "Circularity of customer service experience and customer perceived value," Journal of Customer Behaviour, Vol. 9 No. 1, pp. 37-53.

Hofstede, G. (2020), Hofstede Insights, available online at https://www.hofstede-insights.com/ Accessed 01.04.2020.

Hogarty, G. E. (2002). Personal therapy for schizophrenia and related disorders: A guide to individualized treatment. Guilford Press.

Holdford, D. (2007). Marketing for pharmacists. Washingtion DC: American Pharmacists Association.

Huang, K. Y., Chengalur-Smith, I., and Pinsonneault, A. (2019), "Sharing is caring: social support provision and companionship activities in healthcare virtual support communities", MIS Quarterly, Vol. 43 No. 2, pp. 395-424.

Hulland, J. (1999). Use of partial least squares (PLS) in strategic management research: A review of four recent studies. Strategic Management Journal, Vol. 20 No. 2, pp. 195204.

Iglesias, V. (2004), "Preconceptions about service: how much do they influence quality evaluations?" Journal of Service Research, Vol. 7 No. 1, pp. 90-103.

Joosten, H., Bloemer, J., and Hillebrand, B. (2017). Consumer control in service recovery: beyond decisional control. Journal of Service Management, Vol. 28 No. 3, pp. 499-519.

Judson, K.M. and Taylor, S.A. (2014), "Moving from marketization to marketing of higher education: the co-creation of value in higher education," Higher Education Studies, Vol. 4 No. 1, pp. 51-67.

Karpen, I.O., Bove, L.L. and Lukas, B.A. (2012), "Linking service-dominant logic and strategic business practice: a conceptual model of a service-dominant orientation," Journal of Service Research, Vol. 15 No. 1, pp. 21-38.

Keaveney, S.M. (1995), "Customer Switching Behaviour in Service Industries: An Exploratory Study", Journal of Marketing. Vol. 59 No. 2, pp. 71-82.

Keszey, T. (2018). Boundary spanners' knowledge sharing for innovation success in turbulent times. Journal of Knowledge Management, Vol. 22 No.5, pp. 1061-1081.

Kitson, A., Marshall, A., Bassett, K. and Zeitz, K. (2013), "What are the core elements of patient-centred care? A narrative review and synthesis of the literature from health policy, medicine and nursing", Journal of Advanced Nursing, Vol. 69 No. 1, pp. 4-15.

Kock, N. (2015). Common method bias in PLS-SEM: A full collinearity 
assessment approach. International Journal of E-Collaboration, Vol. 11 No. 4, pp. 110.

Kotler, P. (1976). Marketing management: analysis, planning, and control. Englewood Cliffs, N.J.: Prentice-Hall,

Lamb, Y., Cai, W., and McKenna, B. (2020). "Exploring the complexity of the individualistic culture through social exchange in online reviews", International Journal of Information Management, Vol 54, Article No. 102198.

Lee, K.-C., and Choi, B. (2006), "Six Sigma management activities and their influence on corporate competitiveness", Total Quality Management, Vol. 17 No. 7, pp. 893-911.

Leino, A. (1952), "Planning patient-centered care", The American Journal of Nursing, Vol. 52 No. 3, pp. 324-325.

Li, M., and Cai, L. A. (2012). "The effects of personal values on travel motivation and behavioral intention", Journal of Travel Research, Vol. 51 No. 4, pp. 473-487.

Lutfey, K. (2004), “Assessment, objectivity, \& interaction: The case of patient compliance with medical treatment regimens", Social Psychology Quarterly, Vol. 67 No. 4, pp. 343368.

Mai, S., Ketron, S., \& Yang, J. (2020). "How individualism-collectivism influences consumer responses to the sharing economy: Consociality and promotional type", Psychology \& Marketing, Vol. 37 No. 5, pp. 677-688.

Mattila, A. S., \& Patterson, P. G. (2004). "Service recovery and fairness perceptions in collectivist and individualist contexts", Journal of service research, Vol. 6 No. 4, pp. 336-346.

McColl-Kennedy, J.R., Vargo, S.L., Dagger, S.D., Sweeney, J.C. and van Kasteren, Y. (2012), "Health care customer value co-creation practice styles," Journal of Service Research, Vol. 15 No. 4, pp. 370-89.

McColl-Kennedy, J. R., Hogan, S. J., Witell, L., and Snyder, H. (2017), "Co-creative customer practices: Effects of health care customer value co-creation practices on well-being", Journal of Business Research, Vol. 70, pp. 55-66.

McColl-Kennedy, J. R., Snyder, H., Elg, M., Witell, L., Helkkula, A., Hogan, S. J., \& Anderson, L. (2017). The changing role of the health care customer: review, synthesis and research agenda. Journal of Service Management, Vol. 28 No. 1, pp. 2-33. http://doi.org/10.1108/JOSM-01-2016-0018

Mitchell, T.R. (1974), "Expectancy models of job satisfaction, occupational preference and effort: a theoretical, methodological and empirical appraisal," Psychological Bulletin, Vol. 81 No. 12, pp. 1053-1077.

Michie, S., Miles, J., and Weinman, J. (2003). Patient-centredness in chronic illness: What is it and does it matter? Patient Education and Counseling, Vol. 51 No. 3, pp. 197-206.

Nambisan, P. and Nambisan, S., (2009), "Models of consumer value co-creation in health care", Health care management review, 34(4), pp.344-354.

Neghina, C., Caniëls, M. C. J., Bloemer, J. M. M., \& van Birgelen, M. J. H. (2015). Value cocreation in service interactions: Dimensions and antecedents. Marketing Theory, Vol. 15 No. 2, pp. 221-242.

Neghina, C., MM, B. J., van Birgelen, M. J., \& Caniëls, M. C. (2017). Consumer motives and Willingness to co-create in professional and generic services. Journal of Service Management, Vol. 28 No. 1, pp.1-44.

Neuman, L. W. (2006). Social research methods, qualitative and quantitative approaches (6th ed. ed.). Boston: Pearson Education Inc.

Nicholls, D. A., \& Gibson, B. E. (2012). Editorial. Physiotherapy Theory and Practice, Vol. 28, pp. 418-419. 
Normann, R. (2001), Reframing business: When the map changes the landscape, Hoboken, NJ, John Wiley \& Sons.

O’Hern, M.S. and Rindfleisch, A. (2010), "Customer co-creation," Review of Marketing Research, Vol. 6, pp. 84-106.

Ostrom, A. L., Parasuraman, A., Bowen, D. E., Patrício, L., Voss, C. A., and Lemon, K. (2015), "Service research priorities in a rapidly changing context", Journal of Service Research, Vol. 18 No. 2, pp. 127-159.

Palmgreen, P. (1984), "Uses and gratifications: a theoretical perspective," in Bostrom, R.N. Communications Year Book, Vol. 8, Sage Publications, Beverly Hills, CA, pp. 61-72.

Papadimitriou, C. (2008), "It was hard but you did it": Work in a Clinical Context among Physical Therapists and Spinal Cord Injured Adult" Disability and Rehabilitation, Vol. 30 No. 5, pp. 365-774.

Payne, A.F., Storbacka, K. and Frow, P. (2008), "Managing the co-creation of value", Journal of the Academy of Marketing Science, Vol. 36 No. 1, pp. 83-96.

Rahman, S. U. (2019). "Differences in horizontally individualist and vertically collectivist consumers' environmental behaviour: a regulatory focus perspective", International Journal of Business and Emerging Markets, Vol. 11 No. 1, pp. 73-88.

Rathert, C., Wyrwich, M.D. and Austin Boren, S. (2012), "Patient-centered care and outcomes: a systematic review of the literature", Medical Care Research and Review, Vol. 70 No. 4, pp. 351-379.

Ratneshwar, S., Mick, D.G. and Huffman, C. (2000), The why of consumption: contemporary perspectives on consumer motives, goals, and desires, Vol. 1, Taylor \& Francis Group, London, UK.

Ranjan, K. R., \& Read, S. (2016). Value co-creation: concept and measurement. Journal of the Academy of Marketing Science, 44(3), 290-315.

Ravald, A., and Grönroos, C. (1996). "The value concept and relationship marketing". European journal of marketing. Vol. 30 No. 2, pp. 19-30.

Razmerita, L., Kirchner, K., \& Nielsen, P. (2016). What factors influence knowledge sharing in organizations? A social dilemma perspective of social media communication.

Journal of Knowledge Management, Vol. 20 No. 6, pp. 1225-1246.

Ringle, C., Wende, S., \& Becker, J. M. (2015). SmartPLS 3. Bönningstedt: SmartPLS Retrieved from www.smartpls.com.

Sánchez-Fernández, R. and Iniesta-Bonillo, M.A. (2007), "The concept of perceived value: a systematic review of the research," Marketing Theory, Vol. 7 No. 4, pp. 427-51.

Schüler, M., Fee Maier, M., \& Liljedal, K. T. (2019). Motives and barriers affecting consumers' co-creation in the physical store. The International Review of Retail, Distribution and Consumer Research, 1-22.

Seiders, K., Godfrey Flynn, A., Berry, L. L., \& Haws, K. L. (2015). Motivating customers to adhere to expert advice in professional services: A medical service context. Journal of Service Research, Vol. 18 No. 1, pp. 39-58.

Shaw, J. A., and DeForge, R. T. (2012), "Physiotherapy as bricolage: Theorizing expert practice", Physiotherapy Theory and Practice, Vol. 28 No. 6, pp. 420-427.

Solomon, M.R., Surprenant, C., Czepeil, J.A. and Gutman, E.G. (1985), "A role theory perspective on dyadic interactions: the service encounter," The Journal of Marketing, Vol. 48 No. 1, pp. 99-111.

Starfield, B. (2011), "Is patient-centered care the same as person-focused care?", The Permanente Journal, Vol. 15 No. 2, pp. 63-69.

Street, R. L., Makoul, G., Jr., Neeraj, A. K., and Epstein, R. M. (2009), "How does communication heal? Pathways linking clinician-patient communication to health outcomes", Patient Education and Counseling, Vol. 74 No. 3, pp. 295-330. 
Sweeney, J. C., Danaher, T. S., \& McColl-Kennedy, J. R. (2015). Customer Effort in Value Co-creation Activities. Journal of Service Research, Vol. 18 No. 3, pp. 318-335. https://doi.org/10.1177/1094670515572128

Tobbin, P. (2012), "Towards a model of adoption in mobile banking by the unbanked: a qualitative study", info. Vol. 14 No. 5, pp. 74-88.

Tran, A. N., Haidet, P., Street, R. L., Jr., O'Malley, K. J., Martin, F., \& Ashton, C. M. (2004). Empowering communication: A community-based intervention for patients. Patient Education and Counseling, Vol. 52 No. 1, pp. 113-121.

Turek, A., \& Owczarek, A. (2015). Consumption and consumer behavior in the European healthcare market. In M. Glowik \& S. Smyczek (Eds.), Healthcare: Market dynamics, policies and strategies in Europe. Berlin and Boston: Walter de Gruyter.

Vargo, S.L. and Lusch, R.F. (2004), "Evolving to a new dominant logic for marketing," Journal of Marketing, Vol. 68 No. 1, pp. 1-17.

Vargo, S.L. and Lusch, R.F. (2008), "Service-dominant logic: continuing the evolution," Journal of the Academy of Marketing Science, Vol. 36 No. 1, pp. 1-10.

Vroom, V. (1964), Expectancy Theory. Wiley, New York.

Wigfield, A. and Eccles, J.S. (2000), "Expectancy-value theory of achievement motivation," Contemporary Educational Psychology, Vol. 25 No. 1, pp. 68-81.

Williams, J. and Aitken, R. (2012) 'The Service-Dominant Logic of Marketing and Marketing Ethics', Journal of Business Ethics. Vol. 102 No. 3, pp. 439-54.

World_Confederation_of_Physical_Therapy. (2017). Policy statement: Description of physical therapy. Retrieved May 20, 2017 http://www.wcpt.org/policy/psdescriptionPT

Wright, L. T., Ouschan, R., Sweeney, J., and Johnson, L. (2006), "Customer empowerment and relationship outcomes in healthcare consultations", European Journal of Marketing, Vol. 40 No. 9/10, pp. 1068-1086.

Yi, Y. and Gong, T. (2013), "Customer value co-creation behavior: scale development and validation," Journal of Business Research, Vol. 66 No. 9, pp. 1279-84.

Yi, Y., Nataraajan, R. and Gong, T. (2011), "Customer participation and citizenship behavioral influences on employee performance, satisfaction, commitment, and turnover intention," Journal of Business Research, Vol. 64 No. 1, pp. 87-95. 
Table 1

Inter-construct correlations, Average Variance Extracted (AVE), and the square root of AVE along the diagonal

Germany

\begin{tabular}{llccccccccc}
\hline & Constructs & AVG & 1 & 2 & 3 & 4 & 5 & 6 & 7 & 8 \\
\hline 1 & Co-Creation Behaviour & 0.652 & $\mathbf{0 . 8 0 7}$ & & & & & & & \\
2 & Concerted Motive & 0.729 & 0.292 & $\mathbf{0 . 8 5 4}$ & & & & & & \\
3 & Development Motive & 0.716 & 0.401 & 0.418 & $\mathbf{0 . 8 4 6}$ & & & & & \\
4 & Empowering Motive & 0.681 & 0.252 & 0.415 & 0.534 & $\mathbf{0 . 8 2 5}$ & & & & \\
5 & Ethical Motive & 0.800 & 0.314 & 0.312 & 0.440 & 0.367 & $\mathbf{0 . 8 9 4}$ & & & \\
6 & Individualising Motive & 0.689 & 0.192 & 0.285 & 0.522 & 0.552 & 0.268 & $\mathbf{0 . 8 3 0}$ & & \\
7 & Relating Motive & 0.784 & 0.086 & 0.322 & 0.264 & 0.358 & 0.114 & 0.201 & $\mathbf{0 . 8 8 6}$ & \\
8 & Willingness to Share & 0.670 & 0.469 & 0.216 & 0.382 & 0.333 & 0.216 & 0.321 & 0.035 & $\mathbf{0 . 8 1 9}$ \\
\hline
\end{tabular}

Inter-construct correlations, Average Variance Extracted (AVE), and the square root of AVE along the diagonal

Pakistan

\begin{tabular}{llccccccccc}
\hline & Constructs & AVG & 1 & 2 & 3 & 4 & 5 & 6 & 7 & 8 \\
\hline 1 & Co-Creation Behaviour & 0.884 & $\mathbf{0 . 7 7 8}$ & & & & & & & \\
2 & Concerted Motive & 0.868 & 0.717 & $\mathbf{0 . 8 2 9}$ & & & & & & \\
3 & Development Motive & 0.826 & 0.744 & 0.712 & $\mathbf{0 . 7 8 3}$ & & & & & \\
4 & Empowering Motive & 0.898 & 0.714 & 0.641 & 0.608 & $\mathbf{0 . 8 6 4}$ & & & & \\
5 & Ethical Motive & 0.863 & 0.713 & 0.602 & 0.620 & 0.609 & $\mathbf{0 . 8 2 3}$ & & & \\
6 & Individualising Motive & 0.821 & 0.683 & 0.631 & 0.665 & 0.618 & 0.571 & $\mathbf{0 . 7 7 8}$ & & \\
7 & Relating Motive & 0.767 & 0.473 & 0.362 & 0.361 & 0.470 & 0.561 & 0.402 & $\mathbf{0 . 7 8 9}$ & \\
8 & Willingness to Share & 0.861 & 0.768 & 0.634 & 0.654 & 0.619 & 0.601 & 0.611 & 0.389 & $\mathbf{0 . 8 2 0}$ \\
\hline
\end{tabular}


Table 2

PLS path analysis results (Standardized beta coefficients and $p$-values)

Germany

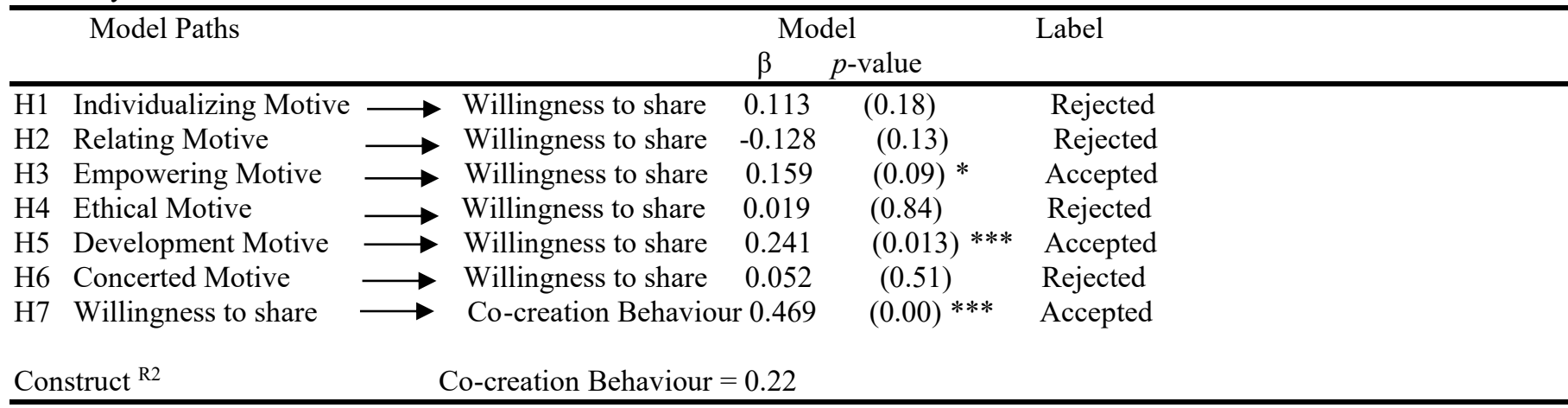

$* \mathrm{p} \leq 0.1{ }^{* *} \mathrm{p} \leq 0.05$.*** $\mathrm{p} \leq 0.01$.

PLS path analysis results (Standardized beta coefficients and $p$-values)

Pakistan

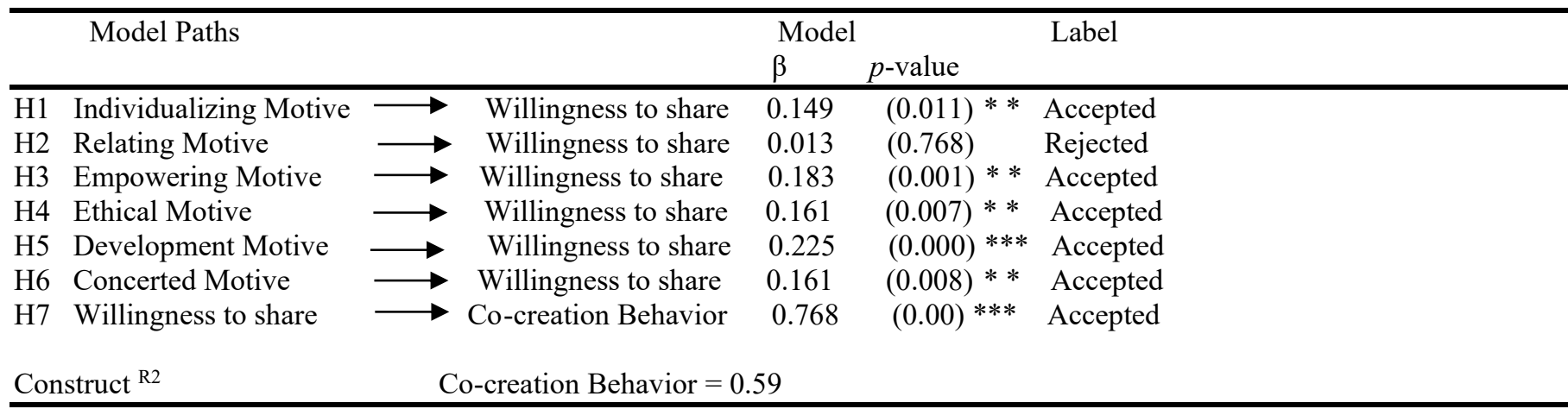

$* \mathrm{p} \leq 0.1{ }^{* *} \mathrm{p} \leq 0.05 . * * * \mathrm{p} \leq 0.01$. 